\title{
新型コロナウイルス感染症と心理学
}

\author{
山田 祐樹 九州大学
}

\section{COVID-19 and Psychology}

Yuki Yamada (Kyushu University)

The Japanese Journal of Psychology

2021, Vol. 92, No. 5, pp. 321-326

J-STAGE Advanced published date: November 30, 2021, https://doi.org/10.4992/jjpsy.92sp.editorial

\section{はじめに}

2019 年末から始まった新型コロナウイルス感染症 （COVID-19）の世界的流行は，本稿を執筆している 2021 年 7 月の時点でも収束の目処が立っていません。 その間に COVID-19 は私達の生活を一変させ, マスク 着用, 手洗い, 物理的距離の拡大といった感染防止対 策やそれに伴う休業・休校, 時差出勤, テレワークな どがもはや日常的なものとなってきました。そして同 様の影響は研究者・教育者・実践家の活動にも現れま した。例えば，対面での授業，実験・調査，心理支援 は従来の形のままでは継続できなくなりました。学会 や研究会といった各種ミーティングも軒並みオンライ ンでの開催へと移行しました。このような状況におい て, 心理学者はどのようにあるべきなのかと多くの 方々が思ったに違いありません。

海外では心理学者たちがいち早く動き始めました。 例えば 2020 年 3 月に Chris Chambers 氏が COVID-19 関連の有審査事前登録論文への迅速査読（なんと一週 間以内）をRoyal Society Open Science 誌にて実施する ことを発表し，世界中のジャーナルへも賛同を求めま した (Chambers, 2020)。そしてその呼びかけから 4 日 後までに Nature Human Behaviour 誌など 9 つのジャー ナルが参画します。翌月には，拈そらくその迅速查読 のイニシアチブのもと, 42 名の研究者がパンデミッ クに関連すると思われるいくつもの心理学的研究卜 ピックについて概説する論文を発表し, COVID-19 禍 下でのさらなる研究の必要性を訴えました（Van Bavel et al., 2020)。こうした一連の情勢を鑑み，日本国内で も心理学者による COVID-19 関連の研究を効果的に促

Correspondence concerning this article should be sent to: Yuki Yamada, Faculty of Arts and Science, Kyushu University, Motooka, Nishi-ku, Fukuoka 819-0395, Japan. (E-mail: yamadayuk@gmail.com)
進することを目指して，2020 年 5 月から特集号の構 想と準備を進めました。心理学研究誌としては創刊以 来初の特集号企画であり，不慣れなことや予測できな いことでいっぱいでした。当初は, 全国的に COVID-19 で大変な時期に, 果たして論文を投稿して 頂ける方がどれだけいるのかという不安もありまし た。ところが蓋を開けてみると投稿論文数はのべ 76 本, そのうち掲載数は 20 本と, 当初の心配は全くの 杞憂であることが分かりました。むしろ，これだけの 数の投稿を適切に一人でハンドリングできるのかとい う恐怖の方が私を慄かせることとなったのです。が, それはさておき，次節からは本特集号の揭載論文につ いてごく簡単に紹介して参ります。

\section{マスク着用・手洗い行動}

掲載論文間にはいくつかの共通点がありましたが, その一つはマスク着用や手洗い行動についてでした。 中谷内・尾崎 - 柴田・横井（2021）は手洗い行動に関 連する要因について, 自他へのリスク低減, 同調, 不 安といった点について調査しました。ところでこの研 究は, 先行して出版されたマスク着用の要因を検討し た Nakayachi, Ozaki, Shibata, \& Yokoi（2020）と共通の データセットを使用していました。榊原・大薗（2021） はこの Nakayachi et al.（2020）とほぼ同時期にリリー スされた Sakakibara \& Ozono（2020）とを比較し, 両 者の結果の再現性を確認しながらそれら調査間に存在 する不一致の原因を探索しました。そしてマスク着用 に影響する要因の変遷については, 宮崎・鎌谷・河原 （2021）が 2018 年から実に 9 波に及ぶ時系列調查を実 施した結果を報告しています。それに加え，鎌谷・伊 藤・宮崎・河原（2021）は, COVID-19 流行前後での 黒色マスク着用者への印象変化についても検討しまし た。また, 山本・岡（2021）は, COVID-19に感染し た人々がマスク着用や手洗い等の感染予防を意ってい 
たかのように推定されてしまうステレオタイプやその 関連要因について調査を行いました。感染予防行動に まつわるこれらの研究においてしばしば取り上げられ たのは感染脆弱意識, 行動免疫システム, ならびに規 範です。今後も続くと思われる COVID-19 禍では，こ れらの要因がますます注目を集めていくことが予想さ れます。

\section{生活変化}

COVID-19 の蔓延に伴う生活の変化も共通して検討 された話題でした。特に，遠隔授業の心理的影響や教 育的効果についての検討は投稿論文の中でも扱われる ことの多いトピックでした。飯田他（2021）は遠隔授 業の受講数や負担感と経済的な負担感が大学生の精神 的健康とどう関連するかを検討しました。同様に，内 田・黒澤（2021）は遠隔授業のために必然的に生じる 視覚表示端末の長時間利用が学生の心身へ与える影響 について調査しました。それに加え, 永井 (2021) は, レポートや課題について真摰に取り組むといった学生 の主体的な学修態度と遠隔授業への適合性の関連を調 べ報告しています。また同様に中尾（2021）では，遠 隔授業が実施され，キャンパスでの活動が制限される 中での学生の精神的健康について, アタッチメントと 孤独感に着目した検討がなされました。この孤独感に ついては, 杉山・廣康・野村・林・四本 (2021) も $\lceil$ Time Social Distancing」という国際共同研究での調查 結果を（睡眠やクロノタイプなど他の測定結果も合わ せて）報告しています。

冒頭で述べたとおり，パンデミック下では単に活動 が制限されただけでなく，多くの教育機関が休業を余 儀なくされました。そこで高坂（2021）は，臨時休業 となった小学校児童における生活習慣の変化が，児童 のストレス反応にどう影響するのかを調べました。そ してもちろん, COVID-19禍によって生活に重大な変 化が生じたのは児童や学生だけではありません。平井・ 渡邊（2021）は乳幼児の育児期にあり配偶者を持つ正 規雇用の男性を対象とし，パンデミックにおける働き 方, 家庭関与, 家庭・仕事満足度の変化やその要因を 検討しました。このように, COVID-19がもたらした 人々の生活におけるさまざまな側面での変化は心理学 の研究対象として取り上げられることが多いです。そ して本特集号の揭載論文が扱っているトピックの他に も無数の題材が潜在的に存在しています。COVID-19 禍による生活変化の影響については，より幅広く多様 な視点からの試みが今後も展開されてゆくでしょう。

\section{臨 床}

遠隔での心理支援や臨床現場特有の問題を扱う研究 も多く見られました。残念ながら本特集号に掲載され ている数は多くありませんが，この話題を扱う論文が
実は最も多く投稿されました。それだけ関心と危機感 を持つ心理学者が多い話題であったとも言えます。上 倉・大川・益子（2021）は, 従来は対人接触とともに 行われる臨床動作法を COVID-19 禍でもそのまま実施 することは困難であるため，対面でも触れずに行うた めの方法を検討し, 統合失調症者に対し適用した結果 を報告しました。國見・岩㟝・荻津・川端・櫻井（2021） は，大学院生等の非専門家が高校生に対し心理支援を 行う取り組みである「キャンパスエイド」を遠隔で実 施する上での運用可能性とありうる問題点について検 討しました。また，このトピックでは現場のスタッフ に着目した研究も多く, 小岩・若島・浅井・高木・吉 井（2021）は COVID-19 への看護師の感染恐怖につい て, 看護師の個人的要因, 労働状況, 対処行動の 3 つ の観点から明らかにしょうとしています。現場では対 面・遠隔どちらを選んだとしても必ず困難が待ってお り，その中で実践家は最善のやり方を求めて常にアッ プデートを重ねています。本トピックについてできる だけ多くの有用な知見が蓄積・共有され，その最適化 の取り組みが大きく促進されることを期待します。

\section{データ, ツール，意見}

本特集号は，募集の際に「COVID-19 に関係するあ らゆる心理学的な論文を募集いたします」と述べてい ました。これに呼応するように, 特集号ならではといっ た論文も数多く投稿されました。その一つが山縣・寺 口・三浦（2021）によるデータペーパーです。この論 文は行動免疫システムに着目し、リスク認知, 感染予 防行動, 感染忌避, 道徳性, 排斥的態度などのほか, COVID-19 への認知, 生活実態, 科学的知識等の測定 をまだ 1 回目の緊急事態宣言が出される前の 2020 年 3 月下旬に実施し, データセットを公開・共有して います。小林（2021）は，COVID-19禍にて急激に需 要が増大しているオンライン実験において, 記述式の テストを行う際の「変換」問題を解決するための lab. js 用のオープンソースプラグインを開発し，それを用 いた実践形式のデモンストレーションを行っていま す。こうした有用性の高いデータセットやッールは, さらなる COVID-19 研究を喚起する上でとても重要で す。

さらに，本特集号には展望論文も多く寄せられまし た。これらは特定の研究トピックについて概観する従 来の展望論文とはやや異なり，COVID-19 禍をさまざ まな視点から議論する「意見」の意味合いを有してい ました。我々はこのような意見を扱う論文については, 示唆性, 論拠の明確さ, 心理学分野との適合性といっ た観点を主に評価いたしました。これらは従来の評価 項目と少し異なる部分もありますので，いくつかの展 望論文については「意見」に属するものであることを 示すため編集委員会からの注橎を入れております。で 
は個別の論文を見ていきます。鬼頭・前田 (2021) は, COVID-19 の感染拡大状況について社会生態学的要因 である関係流動性に着目し，日本における初期の感染 拡大が抑制されたことの考察と，今後の終息が遅れる かもしれないという予測を行っています。木下(2021) は, COVID-19のリスクコミュニケーションに関して 社会心理学・リスク学的視点から議論し, 著者のこれ まで関与してきたケースを吟味しつつ, リスクコミュ ニケーションのあり方や COVID-19 禍そのものについ て実に大局的な考察を提示しました。三田地 (2021) は本特集号募集時の「いま心理学者は何をすべきか」 という問いかけについて, 今はまだ個人や学会のどち らのレベルでも貢献が不十分であり, 心理学者はより 強い覚悟を持って COVID-19 を始めとする社会問題に 挑むべきであると指摘しています。いずれも大変個性 的なメッセージを発しており, このような議論を喚起 できたことはまさに特集号ならではのものでした。

\section{特集号が多り出した諸論点}

ここまで紹介してきたように，本特集号には非常に 多くの意義深い論文が投稿・掲載されております。各 論文の示唆するものについては，それぞれ実際にお読 み頂ければよくお分かりになることと思います。その 他，いくつかの論文は特集号に投稿されたものの審査 の終了が今号に間に合わない等の都合により，一般号 にて揭載されることとなってしまいました。とはいえ， これらの論文にも大変魅力的なものが揃っています。 また本特集号は, COVID-19 が日本でも脅威となり始 めてからほんの 3 力月程度で投稿募集に至りました が,この前例のないスピード感での企画運用は編集委 員会にとって大きな収穫となりました。しかし，こう したポジティブな側面がある一方で, 今回の企画立案 から実際の出版に至る過程において，いくつかの教訓 や問題点も浮き彫りとなってきました。

文献爆発 企画者の立場としては投稿論文数が異例 の多さであったことを純粋に喜んでいるのですが，こ れは世界的には懸念されている傾向でもあります。そ れは,「Covidization」とも呼ばれる COVID-19 パンデ ミック下に打ける発表文献数の急増です（Pai, 2020)。実際に, 参考までに心理学系プレプリントサー バーであるPsyArXivににおるリリース数を見てみる と, 2,358 本 (2018 年), 3,604 本 (2019 年), 6,261 本 $(2020$ 年) というように 2020 年を境に急増しており, 今年もさらにペースが上がって 7 月 25 日の時点で既 に 4,010 本のプレプリントがリリースされています。 $\lceil\mathrm{COVID} 」 と$ 検索するだけで 1,400 本がヒットし，そ の他にも多くの COVID-19 研究が存在する可能性があ ります。プレプリントを指標とするのは妥当性に問題 があるかもしれませんし，単にプレプリントの利用が 普及した時期と一致しただけかもしれません。しかし
ながら, Nature 誌が行ったより詳細な調査でもこの傾 向は明らかとなっています (Else, 2020)。心理学研究 誌でも Japanese Psychological Research 誌でも2020 年 度の投稿論文数は過去最多を記録しました。こうした 論文数の増加が単にステイホームのおかげで研究者に 論文を書く余裕が生まれたためであれば良かったので すが, 実際は COVID-19 という新規な研究トピックに ついての出版競争が起きており，そのために質の低い 論文が量産されていることが問題視されています (Jung et al., 2021)。Retraction Watchによれば, 7 月 25 日時点での COVID-19関連の撤回論文数は既に 147 本 に達しており (https://retractionwatch.com/retractedcoronavirus-covid-19-papers/), 拙速な出版が横行して いる証左となっています。このような文献爆発の原因 と過程を正確に理解し，研究を適正化することが重要 となっていくでしょう。

ファイルドロワー問題 古くから, 研究データの多 くが公表されないまま監入りになっている点が指摘 されてきました (Rosenthal, 1979)。このファイルドロ ワー問題は出版バイアスとセットで語られることが多 く（池田・平石, 2016), つまり有意な結果を報告す る論文でなければ出版されにくいため，有意でない結 果を示した論文のデー夕は公表されないことになりま す。ゆえに, この問題は研究結果の再現性問題と絡め て語られることが多いのです (Francis, 2012)。ところ がそれだけでなく，ファイルドロワー問題は研究倫理 とも関連すると考えています。心理学の研究デー夕は 「人」から得ています。特に COVID-19 禍では, どん な人々ももれなく通常よりも大変な状況下にあり, 参 加者は一定以上の苦しみの中でなんとか研究に協力し てくれています。そのようなデー夕を死蔵させたまま で果たして良いのでしょうか。今回の特集号では，実 に $75 \%$ もの投稿論文の掲載を見送る必要がありまし た。ではそれらの論文が収録していたデー夕はどう なってしまうのでしょうか。今後, 首尾よく別のジャー ナルに掲載されるならば良いのですが，本特集号に揭 載されなかった全ての論文がそのような幸せな結末を 迎えられるとは残念ながら思えません。

この状況を改善するためにはいくつかの手が考えら れます。一つは山縣他 (2021)のようなデータペーパー を積極的に投稿する空気を醸成することでしょう。私 も COVID-19 関連のデータペーパーを出した経験があ りますが (Yamada et al., 2021; Yamada, Xu, \& Sasaki, 2020), 結果の有意性などを気にせずに, デー夕取得 の重要性と測定精度に集中できる研究は開放感があっ て楽しいものでした。同様に, マイクロパブリケーショ ン（Yamada, 2020; 日本語での詳細な説明はこちら： https://note.com/momentumyy/n/n0bfd14103ab7）の形式 で，方法と結果のみに特化した論文が出版可能になる ことが期待されます。注意すべきなのは，こうして単 
にデータだけ報告しやすくしても，そのデータのクオ リティが低ければ二次分析やメ夕分析に使うことはで きないということです (“Garbage In, Garbage Out”)。 そのため, なんと言ってもやはり有審査事前登録論文 を国内誌 (心理学研究誌を含む) ももっと扱っていく べきということになります（長谷川他，2021）。この 方式では, デー夕収集前に研究プロトコルへの查読を 通過した研究は結果の如何を問わずに原則的に出版が 保証されるため, ファイルドロワー問題を回避でき, 查読によって測定精度の問題も解消できます。本特集 号の審査では, 研究対象の面白さや貴重さはずば抜け ていても，測定方法に難があったため揭載を見送ると いうケースがいくつもありました。ですがこれらは データ収集前にプロトコルに対して査読を行い修正す ればほとんどが解決できるもので，とても勿体ないと 感じていました。

では, プロトコルに対して査読を受けていたらデー 夕を取る「旬」を逃してしまうのでしょうか？ 先に 述べた Royal Society Open Science 誌の実施した迅速査 読を我々は体験してみましたが (Yonemitsu et al., 2020)，どれだけ早く開始できるかは著者次第かもし れません。というのも，査読は必ず7 日以内に完了し たため, 著者側がそれに迅速に対処できるかどうかで 調查開始までの期間が全て決まりました。かといって 查読が杜撰に行われたわけではなく，むしろ過去最多 の查読者（5名）による過去最多のコメント量でした (公開されている査読履歴は 119 ページもあります)。 国内誌でも専用の查読システムさえ構築できれば同様 の迅速な取り組みが実現できるのかもしれません。同 時にそのような査読システムでは查読者が圧倒的に不 足する状況が生じ得ますが, Royal Society Open Science 誌では査読者のプール化がテストされています。この 取組は他のジャーナルも参考にできると思います。

倫理審査 倫理審査については現在とても複雑な状 況にあると考えられます。倫理審査を義務付けること によって, 研究倫理審査委員会を設置できない機関に 所属される方や，所属自体がない方からの投稿を妨げ ることはできません。実際，本特集号に投稿された論 文にも倫理審査を受けられなかったものが存在しまし た。おそらくその理由の多くは, 狙っている時期のデー 夕取得に審査が間に合わなかったためではないかと推 察します。しかし，ある査読者は「災害などの特殊か つ緊急の事情がある時には, 所属機関の研究倫理委員 会をバイパスして研究を実施して良いという暗黙の ルールが，研究者社会に醸成される恐れを繋念する」 とコメントしました。研究倫理が何のために存在する のかを考えると, 研究行為によって損害を受けやすい 参加者や資料などの対象の保護やあるいは研究公正の ためであり，それが災害時に茂ろにされるのは本末転 倒なのです。むしろそのような時こそ, 適正な研究で
あることの確認と保証がしっかりとなされるべきで しょう。

では, 即時に倫理審査を受けられないような緊急性 の高い研究は諦める方が良いのでしょうか？ おそら くですが，リスク認知や社会心理学など災害時の心理 を研究対象とされている方々は平時から緊急時を想定 した研究計画を立て, 事前に審査を通されているのか もしれません。所属機関にこうした申請を認めている 倫理委員会があればそれを活用するのが良いでしょ う。ところが，パンデミックのような世界的災害が発 生し, 多様なサンプルを多角的に研究する多国間のコ ラボレーションが重要となる事態を考えてみますと, それを平時から想定しておくことはかなり難しくなっ てきます。緊急時にも機動的に倫理審査の機能を提供 する独立した審査機関の設立構想まで含め, 倫理審査 のシステムについては今後も活発な議論が必要に感じ ます。

意見表明の場 本特集号での「意見」に相当する展 望論文の審査において，ある查読者から「会員の意見 を吸い上げるプラットフォームが学会内にあってもよ いのではと思いました」とのコメントも頂きました。 どのような形でそれを実現するのが相応しいかについ ては議論を重ねる必要がありますが，今回の特集号企 画を通して, 会員からのニーズが確実に存在している ことは明らかとなりました。今後の課題として学会内 で前向きに検討されることを期待します。

\section{特集を編集していくうえでの技術的な改善可能性}

ここまでの話の他にも，初めての特集号の実践から 見えてきたいくつかの改善可能な点について挙げてみ ます。冒頭で述べたように, 今回の特集号には予想を 遥かに超えるご投稿を頂きました。このことは大変あ りがたい一方で，私の処理限界を超えてしまうことも 意味していました。ゆえに第一に，特集号の担当編集 委員にはチームを組織するのが良いだろうと身に沁み て感じました。次に, 他誌では多く取り入れられてい ますが，本誌でも事前登録制度を導入する必要がある のではと考えました。これは長谷川他（2021）の説明 するいわゆるプレレジの意味ではなく（プレレジも役 立つと思いますが),「投稿の登録」のことです。本 特集号では新規な取り組みとして, 投稿前質問 (pre-submission inquiry) を導入しておりました。これ は元々, トピック違いの投稿の可能性を懸念して用意 していたのですが，むしろこの投稿前質問を簡易スク リーニング (トリアージ ) といった形で, 事前登録シ ステムの一部として活用するのが有効かもしれません。

もう一つは査読の事前依頼です。査読者の先生方も 非常に扔忙しく，こちらがお願いしたタイミングです ぐに審査いただくことは大変困難です。前述のような 事前登録をしておけば，予定される投稿のタイミング 
に合わせて事前に查読候補者に連絡を取り，查読をス ケジュールしておくことが可能になり，今よりスムー ズに審查が行えるかもしれません。私が運営委員とし て参画しているPCI Registered Reports という出版組織 があるのですが，そこで行われている Scheduled Review (https://rr.peercommunityin.org/help/guide_for_auth ors\#h 61998243643551613309672490）という方式の査 読プロセスで実際に同様の経験をしました。ここでは 事前にスナップショットと呼ばれる研究内容の要約を 投稿し, 查読可であるとトリアージされた場合に限り， 完成版原稿の投稿予定日が設定され，査読者が手配さ れます。この方法により, 我々の原稿は 5 日間で查読 が終わりました。査読者側もいつ査読すればよいかが 事前に分かるので予定を空けやすいようです。同様の 方法を特集号で採用するのは比較的容易なのではない かと思われます。

\section{おわりに}

いろいろと述べて来ましたが，総じて本特集号はや はり画期的な取り組みであったと思います。収録され た論文はどれも魅力的ですし，学術的にも制度的にも 見えてきた諸問題はどれも重要です。本特集号の編集 を担当するにあたり，このような稀有な機会を与えて くださった編集担当常務理事の原田 悦子先生, 心理 学研究編集小委員会正副委員長として常に親身になっ てサポートして頂いた中村 知靖先生, 浅野 倫子先生, 上瀬 由美子先生, 深谷 達史先生, そしてご協力とご 理解を賜った機関誌等編集委員会委員の先生方に大き な感謝を捧げます。次に, 数ある出版先候補の中から 本特集号を投稿先に選んで頂いた述べ 229 名の著者の 方々，そしてそれを扎忙しいなか審査して頂いた述べ 179 名の查読者の方々にも深く御礼を申し上げます。 そして何より，本特集号の論文を手にとって頂き，今 後の糧とし, COVID-19 パンデミックによる大きな変 化を経た未来の心理学を共に創造してくださる読者の 皆様。いち心理学者として, 同志として, 皆様と共に 歩めることに心からの喜びを申し上げます。

\section{引用文献}

Chambers, C. (2020). Calling all scientists: Rapid evaluation of COVID19-related registered reports at royal society open science. NeuroChambers. Retrieved from http://neurochambers.blogspot.com/2020/03/ calling-all-scientists-rapid-evaluation.html (March 16, 2020)

Else, H. (2020). How a torrent of COVID science changed research publishing - in seven charts. Nature, 588(7839), 553. https://doi.org/10.1038/d41586-02003564-y

Francis, G. (2012). Publication bias and the failure of repli- cation in experimental psychology. Psychonomic Bulletin \& Review, 19, 975-991. https://doi.org/10.3758/ s13423-012-0322-y

長谷川 龍樹 - 多田 奏恵 - 米満 文哉 - 池田 鮎美 - 山 田 祐樹・高橋 康介・近藤 洋史 (2021). 実証的 研究の事前登録の現状と実践—OSF 事前登録 チュートリアル—— 心理学研究, 92, 188-196. https://doi.org/10.4992/jjpsy.92.20217

平井 美佳・渡邊 寛 (2021). 乳幼児の父親における パンデミックによる働き方の変化と家庭と仕事へ の影響 心理学研究, 92,417-427.

飯田 昭人 - 水野 君平 - 入江 智也 - 川崎 直樹 - 斉 藤 美香・西村 貴之 (2021). 新型コロナウイル 又感染拡大状況に扔ける遠隔授業環境や経済的負 担感と大学生の精神的健康の関連 心理学研究, 92, 367-373.

池田 功毅 ・平石 界 (2016)。 心理学に扮ける再現可 能性危機——問題の構造と解決策— 心理学評 論, 59, 3-14. https://doi.org/10.24602/sjpr.59.1_3

Jung, R. G., Di Santo, P., Clifford, C., Prosperi-Porta, G., Skanes, S., Hung, A., ... Hibbert, B. (2021). Methodological quality of COVID-19 clinical research. Nature Communications, 12, 943, https://doi.org/10.1038/ s41467-021-21220-5

鎌谷 美希·伊藤 資浩·宮崎 由樹·河原 純一郎 (2021). COVID-19 流行が黒色衛生マスク着用者への顕在 的・潜在的態度に及ぼす影響 心理学研究, 92 , 350-359.

上倉 安代・大川一郎・益子 洋人 (2021)。コロナ禍 における統合失調症者を対象とした触れない動作 法の試み 心理学研究, 92, 428-434.

木下 冨雄(2021). 深層防護とリスクコミュニケーショ ン一一大規模感染症に対する社会心理学からの貢 献—— 心理学研究, 92, 482-494.

鬼頭 美江・前田 友吾 (2021). COVID-19 の感染拡 大および終息に与える関係流動性の影響——社会 生態学的視点からの考察— 心理学研究, 92, 473-481.

小林 正法 (2021). 再生テストに基づく記憶現象のオ ンライン実験による再現 心理学研究, 92, 463472.

小岩広平・若島 孔文・浅井継悟 - 高木 源 - 吉 井 初美 (2021)。我が国における看護師の新型コ ロナウイルス感染症への感染恐怖の規定要因 心 理学研究, 92, 442-451.

高坂 康雅 (2021). 親の認知した臨時休業中の小学生 の生活習慣の変化とストレス反応との関連 心理 学研究, 92, 408-416.

國見 充展・岩㠃 眞和・荻津 智絵・川端 珠美 - 櫻 井 由美子 (2021)。キャンパスエイド活動に扩け る遠隔心理支援の試み 心理学研究, 92, 435441.

三田地 真実 (2021).コロナ禍での心理学者の果たす べき役割とは何か? 一人々の声を聴いて行動を 起こす必要性—— 心理学研究, 92, 495-503.

宮崎 由樹 - 鎌谷 美希 - 河原 純一郎 (2021)。社交不 安・特性不安・感染脆弱意識が衛生マスク着用頻 度に及ぼす影響 心理学研究, 92,339-349. 
永井 暁行 (2021). コロナ禍の非対面授業における学 生の主体的な学修態度——非対面授業との適合と の関連——理学研究, 92, 384-389.

中尾 達馬(2021). コロナ禍での大学生におけるアタッ チメントと孤独感や精神的健康との経時的な相互 関係 心理学研究, 92, 390-396.

Nakayachi, K., Ozaki, T., Shibata, Y., \& Yokoi, R. (2020). Why do Japanese people use masks against COVID-19, even though masks are unlikely to offer protection from infection? Frontiers in Psychology, 11, 1918. https://doi.org/10.3389/fpsyg.2020.01918

中谷内一也·尾崎 拓·柴田 侑秀·横井 良典 (2021). 新型コロナウイルス拡大期における手洗い行動の 規定因 心理学研究, 92, 327-331.

Pai, M. (2020). Covidization of research: What are the risks? Nature Medicine, 26(8), 1159. https://doi. org/10.1038/s41591-020-1015-0.

Rosenthal, R. (1979). The file drawer problem and tolerance for null results. Psychological Bulletin, 86, 638641. https://doi.org/10.1037/0033-2909.86.3.638

Sakakibara, R., \& Ozono, H. (2020). Psychological research on the COVID-19 crisis in Japan: Focusing on infection preventive behaviors, future prospects, and information dissemination behaviors. PsyArXiv. https://doi.org/10.31234/osf.io/97zye

榊原 良太・大䓢 博記 (2021)。人々がマスクを着用 する理由とは一一国内研究の追試とリサーチクエ スチョンの検証—— 心理学研究, 92, 332-338.

杉山 翔吾・廣康 衣里紗まり ・野村 圭史・林 正道・ 四本 裕子 (2021). 外出規制が孤独感・不安・抑 うつに及ぼす影響——日本在住者を対象とした縦 断的研究—— 心理学研究, 92,397-407.

内田 知宏・黒澤 泰 (2021). コロナ禍に入学した大
学一年生とオンライン授業—心身状態とひきこ もり願望——理学研究, 92, 374-383.

Van Bavel, J. J., Baicker, K., Boggio, P. S., Capraro, V., Cichocka, A., Cikara, M., ... Willer, R. (2020). Using social and behavioural science to support COVID-19 pandemic response. Nature Human Behaviour, 4, 460471. http://doi.org/10.1038/s41562-020-0884-z

Yamada, Y. (2020). Micropublishing during and after the COVID-19 era. Collabra: Psychology, 6(1), 36. https://doi.org/10.1525/collabra.370

Yamada, Y., Ćepulić, D., Coll-Martín, T., Debove, S., Gautreau, G., Han, H., ...Lieberoth, A. (2021). COVIDiSTRESS Global Survey dataset on psychological and behavioural consequences of the COVID-19 outbreak. Scientific Data, 8, 3. https://doi.org/10.1038/ s41597-020-00784-9

Yamada, Y., Xu, H., \& Sasaki, K. (2020). A dataset for the perceived vulnerability to disease scale in Japan before the spread of COVID-19. F1000Research, 9, 334. https://doi.org/10.12688/f1000research.23713.2

山縣 芽生・寺口司・ 三浦 麻子 (2021). COVID-19 禍の日本社会と心理一 -2020 年 3 月下旬実施調 査に基づく検討—— 心理学研究, 92, 452-462.

山本 真菜・岡 隆 (2021). 新型コロナウイルス感染 者に対するステレオタイプと行動免疫システム活 性化の個人差との関連 心理学研究, 92, 360366.

Yonemitsu, F., Ikeda, A., Yoshimura, N., Takashima, K., Mori, Y., Sasaki, K., ... Yamada, Y. (2020). Warning "Don't spread" vs. "Don't be a spreader" to prevent the COVID-19 pandemic. Royal Society Open Science, 7, 200793. https://doi.org/10.1098/rsos.200793 